\title{
Nursing diagnoses validated in cardiology in Brazil: integrative literature review*
}

\author{
Diagnósticos de Enfermagem validados em Cardiologia no Brasil: revisão integrativa de literatura \\ Diagnósticos de Enfermería validados en Cardiología en el Brasil: revisión integrativa de literatura
}

\author{
Camila Takáo Lopes ${ }^{1}$, Camila de Souza Carneiro ${ }^{2}$, Vinicius Batista Santos ${ }^{3}$, Alba \\ Lúcia Bottura Leite de Barros ${ }^{4}$
}

\begin{abstract}
Objective: To identify nursing diagnoses (ND) currently appearing in the NANDA-I taxonomy, validated in the area of cardiology in Brazil. Methods: An integrative literature review, guided by the following question: what nursing diagnoses were validated in Brazil? Eleven works were analyzed: three content validations and eight clinical validations. Results: The NDs validated were: activity intolerance, decreased cardiac output, spiritual distress, deficient knowledge, excessive fluid volume, ineffective airway clearance, ineffective peripheral tissue perfusion, fear, anxiety, and pain. The highlights were the production of the graduate programs in public institutions, the validation of defining characteristics, models of validation and the modified Fehring criteria for selection of experts. The clinical validation model was used for NDs of the psychobiological sphere; the content validation model was used mainly for NDs in the psychosocial and psychospiritual spheres. Conclusion: The knowledge produced can provide a basis for future studies on the relevance of the content of nursing outcomes in the evaluation of the effectiveness of nursing interventions in the country.
\end{abstract}

Keywords: Validation studies; Nursing diagnosis; Cardiology

\section{RESUMO}

Objetivo: Identificar diagnósticos de enfermagem (DEs) que constam atualmente na taxonomia NANDA, validados na área de Cardiologia no Brasil. Métodos: Revisão integrativa de literatura, norteada pela seguinte questão: quais diagnósticos de enfermagem foram validados no Brasil. Foram analisados 11 trabalhos: três validações de conteúdo e oito validações clínicas. Resultados: Os DEs validados foram Intolerância à Atividade, Débito Cardíaco Diminuido, Angústia Espiritual, Conhecimento deficiente, Volume Excessivo de Líquidos, Desobstrução Ineficaz de Vias Aéreas, Perfusão Tissular Periférica Ineficaz, Medo, Ansiedade e Dor. Destacaram-se a produção da Pós-Graduação de instituições públicas, a validação das características definidoras, modelos de validação e critérios de seleção de experts de Fehring modificados. O modelo de validação clínica foi usado para DEs da esfera psicobiológica; o modelo de validação de conteúdo foi utilizado sobretudo para DEs das esferas psicossocial e psicoespiritual. O conhecimento produzido pode embasar futuros estudos sobre a pertinência do conteúdo dos resultados de enfermagem na avaliação de eficácia das intervenções de enfermagem no País.

Descritores: Estudos de validação; Diagnóstico de enfermagem; Cardiologia

\section{RESUMEN}

Objetivo: Identificar diagnósticos de enfermería (DEs) que se encuentran actualmente en la taxonomía de la NANDA, validados en el área de Cardiología en el Brasil. Métodos: Revisión integrativa de literatura, orientada por la siguiente pregunta:qué diagnósticos de enfermería fueron validados en el Brasil. Fueron analizados 11 trabajos: tres validaciones de contenido y ocho validaciones clínicas. Resultados: Los DEs validados fueron Intolerancia a la Actividad, Débito Cardiaco Disminuido, Angustia Espiritual, Conocimiento deficiente, Volumen Excesivo de Líquidos, Desobstrucción Ineficaz de Vias Aéreas, Perfusión Tisular Periférica Ineficaz, Miedo, Ansieda y dolor. Se destacaron la producción del Postgrado de instituciones públicas, la validación de las características definitorias, modelos de validación y criterios de selección de experts de Fehring modificados. El modelo de validación clínica fue usado para DEs de la esfera psicobiológica; el modelo de validación de contenido fue utilizado, sobre todo para DEs de las esferas psicosocial y psicoespiritual. El conocimiento producido puede ser fundamentación de futuros estudios sobre la pertinencia del contenido de los resultados de enfermería en la evaluación de la eficacia de las intervenciones de enfermería en el País.

Descriptores: Estudios de validación; Diagnóstico de enfermería; Cardiología

\footnotetext{
* Conclusion study of the Cardiology Nurse Specialist course, Paulista School of Nursing, Federal University of São Paulo (UNIFESP), Brazil.

${ }^{1}$ Master's degree in Sciences. Nurse at Instituto Dante Pazzanese de Cardiologia-SP, Brazil.

${ }^{2}$ Master's degree in Nursing. Nurse at Hospital São Paulo-SP, Brasil.

${ }^{3}$ Nurse in charge, Cardiology Unit, Hospital São Paulo-SP, Brasil.

${ }^{4}$ PhD, Full professor, Paulista School of Nursing, Federal University of São Paulo (UNIFESP) São Paulo, Brasil.
} 


\section{INTRODUCTION}

Interventions in the field of cardiology require sophisticated and often innovative technology, which demand versatility and specialized professional skills. In this context, continuous updating and improvement of nursing care are required. In order to systematically organize the conditions needed for professional care, and thereby support adequate and individualized assistance, the nursing process (NP) is used ${ }^{(1,2)}$.

The nursing phenomena covered within the NP are nursing diagnoses (NDs), interventions and outcomes. NDs are important because they direct the proposed interventions exclusively under the nurses' responsibility, related to the human responses to identified health problems, aiming at the best outcomes ${ }^{(3)}$.

The NDs approved by NANDA International (NANDA-I) are currently organized in Taxonomy II, structured in domains, classes and nursing diagnoses ${ }^{(4)}$. Ever since nurses officially started naming the phenomena they diagnose, there has been the need to validate their existence. There are few defining characteristics (DC) nurses agree on as commonly identifiable and adequate for the diagnostic label. The process of validation is the gathering of evidence that nurses actually identify common DCs ${ }^{(5)}$.

Different models can be used to validate NDs. The best known models are those by Gordon \& Sweeney ${ }^{(6)}$, Fehring $^{(5)}$ and Hoskins ${ }^{(7)}$. Knowing NDs validated in the field of cardiology, in Brazil, facilitates the use of the concepts so that quality choices of interventions and outcomes can be made, knowledge gaps can be identified and new studies in the field can be proposed.

This study aimed at identifying the following in the literature: those NDs currently approved by NANDA-I, validated in the field of cardiology in Brazil; types of validation; components validated; validation models; expert selection criteria; and, the type of institution of origin of the main author (public or private).

\section{METHODS}

An integrative review of the literature was performed to answer the question "Which nursing diagnoses in the field of cardiology have been validated in Brazil?"

The search was conducted in December of 2010, in LILACS, SCIELO and Medline databases using the descriptor "nursing diagnosis", the term "validation" and the country of publication "Brazil". Original articles published between January 2005 and December 2010 were included.

We also used as sources of information Biblioteca Digital Brasileira de Teses e Dissertações (Brazilian Digital
Library of Theses and Dissertations, BDTD), where the terms "validation" and "nursing diagnosis" were used in the field Title and Banco de Teses CAPES (CAPES Theses Database), where the term "nursing diagnosis" was used in the Subject field.

In the Directory of Research Groups (RGs) of the Brazilian National Council for Scientific and Technological Development (CNPq), we searched for RGs using the terms "nursing classifications" and "nursing care systematization". The search resulted in theses and dissertations which we retrieved from the online libraries of every institution whose RGs were included in the Research Fields (RF) Nursing and Public Health, or whose leaders were nurses. RGs in the Medical Research Field were excluded.

We included research in Portuguese, English and Spanish performed in Brazil which validated NDs currently approved by NANDA-I in the field of Cardiology. Theses and dissertations were substituted by their respective published articles when available.

\section{RESULTS}

In LILACS database, 32 articles were retrieved, out of which two validated NDs in the field of cardiology. Seven articles were found in the SCIELO and Medline databases, but none in the field of cardiology. In the CAPES Theses Deposit, 215 studies were retrieved, out of which five validated NDs in the field of cardiology. In the BDTD, 11 studies were retrieved, out of which five validated NDs in the field of cardiology. By using the term "nursing classifications" in the Directory of RGs of CNPq, five RGs were retrieved, and by using the term "nursing care systematization", 35 RGs were retrieved. Out of the 40 RGs, $36(90 \%)$ were in the RF of Nursing.

Among the 37 RGs selected to be sources of dissertations and theses, RGs in the Southeastern region of Brazil prevailed (43\%), followed by the Northeastern $(27 \%)$, Southern (16.2\%), Mid-Western (8.1\%) and Northern regions $(5.4 \%)$. The 37 selected RGs were distributed across 34 institutions, among which $64.7 \%$ were public and federal, $17.6 \%$ were public and state-related and $14.7 \%$ were private.

Five studies addressing validation of NDs in the field of cardiology were retrieved in the digital libraries of the institutions where RGs were based, but all of them had already been found in the other databases. The final sample contained $11(28.9 \%)$ studies - six original articles, three master's theses, and one $\mathrm{PhD}$ doctoral dissertation - and one manuscript accepted for publication in 2011 in the International Journal of Nursing Terminologies and Classifications. The characteristics of the studies are described in Table 1. 
Table 1. Studies included in the integrative review. São Paulo, 2012.

\begin{tabular}{|c|c|c|c|c|c|}
\hline Title & Author(s) & $\begin{array}{l}\text { Year / } \\
\text { Country }\end{array}$ & $\begin{array}{l}\text { Study } \\
\text { design }\end{array}$ & Interventions & Results \\
\hline $\begin{array}{l}\text { Nursing of activity } \\
\text { intolerance: Clinical } \\
\text { validation in patients } \\
\text { with refractory } \\
\text { angina }^{(8)}\end{array}$ & $\begin{array}{l}\text { Rodrigues } \\
\text { CG, Moraes } \\
\text { MA, Sauer } \\
\text { JM, Kalil } \\
\text { RAK, Souza } \\
\text { EN }\end{array}$ & $\begin{array}{l}2011 / \\
\text { Brazil }\end{array}$ & $\begin{array}{l}\text { Clinical } \\
\text { validation, } \\
\text { Fehring's } \\
\text { model }\end{array}$ & $\begin{array}{l}\text { Clinical } \\
\text { assessment } \\
\text { by two expert } \\
\text { nurses }\end{array}$ & $\begin{array}{l}\text { Major DCs: EKG changes reflecting ischemia, verbal } \\
\text { report of fatigue, abnormal blood rate response to activity } \\
\text { Minor DCs: exertional discomfort, exertional dyspnea, } \\
\text { verbal report of weakness and abnormal blood pressure } \\
\text { response to activity }\end{array}$ \\
\hline $\begin{array}{l}\text { Content validation } \\
\text { of current and } \\
\text { new defining } \\
\text { characteristics } \\
\text { of the nursing } \\
\text { diagnosis: decreased } \\
\text { cardiac output }^{(9)}\end{array}$ & $\begin{array}{l}\text { Lopes JL, } \\
\text { Altino D, } \\
\text { Silva RCG }\end{array}$ & $\begin{array}{l}2010 / \\
\text { Brazil }\end{array}$ & $\begin{array}{l}\text { Content } \\
\text { validation, } \\
\text { Fehring's } \\
\text { model }\end{array}$ & Not applicable & $\begin{array}{l}\text { Major DCs: Decreased cardiac output, decreased cardiac } \\
\text { index, decreased peripheral pulses, decreased blood lactate } \\
\text { level, decreased venous oxygen saturation, decreased peripheral } \\
\text { capillary perfusion. } \\
\text { Minor DCs: Oliguria or anuria, decreased left ventricular } \\
\text { stroke index, decreased stroke volume index, decreased left } \\
\text { ventricular ejection fraction, increased heart rate, low blood } \\
\text { pressure, altered systemic vascular resistance, increased } \\
\text { pulmonary capillary wedge pressure, altered left ventricular } \\
\text { filling pressure, altered central venous pressure, increased } \\
\text { levels of brain natriuretic peptide, altered oxygen delivery, } \\
\text { altered pulmonary vascular resistance, changes in skin color, } \\
\text { altered respiratory pattern, altered oxygen uptake, jugular } \\
\text { stasis, altered fluid balance, increased cardiac area, altered } \\
\text { skin temperature, dilated heart chambers, metabolic acidosis, } \\
\text { activity intolerance, CO gap, tiredness / fatigue, increased } \\
\text { levels of atrial natriuretic peptide, increased catecholamine } \\
\text { levels, sleepiness / mental confusion, crackles, cardiac cachexia, } \\
\text { S3 sound, bypoxemia. }\end{array}$ \\
\hline $\begin{array}{l}\text { Content validation } \\
\text { of the "deficient } \\
\text { knowledge" nursing } \\
\text { diagnosis }\end{array}$ & $\begin{array}{l}\text { Galdeano } \\
\text { LE, Rossi } \\
\text { LA, } \\
\text { Pelegrino } \\
\text { FM. }\end{array}$ & $\begin{array}{l}2008 / \\
\text { Brazil }\end{array}$ & $\begin{array}{l}\text { Content } \\
\text { validation, } \\
\text { Fehring's } \\
\text { model }\end{array}$ & Not applicable & $\begin{array}{l}\text { Major DCs: Verbalization of the problem, inaccurate } \\
\text { performance of test, expressing incorrect perceptions about } \\
\text { one's health state } \\
\text { Minor DCs: Inadequate compliance with instructions, } \\
\text { lack of recall, non-verbal indicators of low comprehension, } \\
\text { repeated questioning, information misinterpretation, non- } \\
\text { compliance with the prescribed therapy, non-verbal indicators } \\
\text { of lack of attention, lack of integration between the } \\
\text { treatment plan and daily activities, expressing psychological } \\
\text { alterations (anxiety, depression), inappropriate or exaggerated } \\
\text { behaviors. }\end{array}$ \\
\hline
\end{tabular}

\begin{tabular}{|c|c|c|c|c|c|}
\hline $\begin{array}{l}\text { Ineffective } \\
\text { peripheral tissue } \\
\text { perfusion: Clinical } \\
\text { validation inpatients } \\
\text { With hypertensive } \\
\text { cardiomiopathy }^{(11)}\end{array}$ & $\begin{array}{l}\text { Silva RCG, } \\
\text { Cruz } \\
\text { DALM, } \\
\text { Bortolotto } \\
\text { LA, } \\
\text { Irigoyen } \\
\text { MCC, } \\
\text { Krieger EM, } \\
\text { Palomo JSH } \\
\text { et al }\end{array}$ & $\begin{array}{l}\text { 2006/ } \\
\text { Brazil }\end{array}$ & $\begin{array}{l}\text { Content } \\
\text { and clinical } \\
\text { validation, } \\
\text { Fehring's }\end{array}$ & $\begin{array}{l}\text { Not applicable } \\
\text { to the content } \\
\text { validation. To } \\
\text { the clinical } \\
\text { validation, } \\
\text { clinical } \\
\text { assessment } \\
\text { by the main } \\
\text { researcher }\end{array}$ & $\begin{array}{l}\text { Major DCs: Altered skin color, altered skin temperature, } \\
\text { delayed cicatrization, altered sensations: thermal, altered } \\
\text { sensations: tactile. } \\
\text { Minor DCs: altered skin characteristics: hair, left } \\
\text { ventricular overload, intermittent claudication, altered skin } \\
\text { characteristics: moisture, weak or absent pulses, altered } \\
\text { capillary refill time, altered skin characteristics: nail, } \\
\text { paresthesias, altered skin temperature, altered muscular } \\
\text { function, leg pain at rest, ulcers and gangrene, lucent skin. }\end{array}$ \\
\hline $\begin{array}{l}\text { Decreased cardiac } \\
\text { output diagnosis: } \\
\text { clinical validation in } \\
\text { post-operative heart } \\
\text { surgery patients }{ }^{(12)}\end{array}$ & $\begin{array}{l}\text { Oliva } \\
\text { APV, Cruz } \\
\text { DALM }\end{array}$ & $\begin{array}{l}2002 / \\
\text { Brazil }\end{array}$ & $\begin{array}{l}\text { Clinical } \\
\text { validation, } \\
\text { Fehring's }\end{array}$ & $\begin{array}{l}\text { Clinical } \\
\text { assessment. } \\
\text { Professional } \\
\text { category of the } \\
\text { examiner was not } \\
\text { disclosed }\end{array}$ & $\begin{array}{l}\text { DCs with statistically superior frequency in patients } \\
\text { with decreased cardiac index when compared to } \\
\text { patients with non-decreased cardiac index: filiform } \\
\text { pulse and decreased peripheral perfusion. } \\
\text { These DCs were considered valid to support } \\
\text { decreased cardiac output in the studied sample. }\end{array}$ \\
\hline $\begin{array}{l}\text { Pain: Clinical } \\
\text { Validation With } \\
\text { Postoperative Heart } \\
\text { Surgery Patients }^{(13)}\end{array}$ & $\begin{array}{l}\text { Correa } \\
\text { CG, Cruz } \\
\text { DALM }\end{array}$ & $\begin{array}{l}2000 / \\
\text { Brazil }\end{array}$ & $\begin{array}{l}\text { Clinical } \\
\text { validation, } \\
\text { Gordon \& } \\
\text { Sweeney's, } \\
\text { Fehring's and } \\
\text { Carlson- } \\
\text { Catalano \& } \\
\text { Lunney's } \\
\text { models }\end{array}$ & $\begin{array}{l}\text { Clinical } \\
\text { assessment } \\
\text { by two expert } \\
\text { nurses and one } \\
\text { pain specialist } \\
\text { psychologist }\end{array}$ & $\begin{array}{l}\text { Major DCs: Verbal report of pain, discomfort, fear of } \\
\text { reinjury, sleep disturbance, anorexia, guarding behavior, } \\
\text { distraction behavior, irritability, restlessness, facial mask of } \\
\text { pain, increased beart rate, immobility. } \\
\text { Minor DCs: Anxiety, inability to continue previous } \\
\text { activities, loss of appetite, self-focus, withdrawal, impaired } \\
\text { thought process, unusual posture, increased blood pressure, } \\
\text { changes in respiratory patterns: respiratory frequency, } \\
\text { reduction in amplitude. } \\
\text { Irrelevant DCs: Nausea, frustration, constipation, } \\
\text { diarrbea, depression, hopelessness, low self-esteem, changes in } \\
\text { body weight, alteration in muscle tone, diaphoresis, pupillary } \\
\text { dilation. }\end{array}$ \\
\hline
\end{tabular}




\begin{tabular}{|c|c|c|c|c|c|}
\hline Title & Author(s) & $\begin{array}{l}\text { Year / } \\
\text { Country }\end{array}$ & $\begin{array}{l}\begin{array}{l}\text { Study } \\
\text { design }\end{array} \\
\end{array}$ & Interventions & Results \\
\hline $\begin{array}{l}\text { Identification } \\
\text { of defining } \\
\text { characteristics } \\
\text { of the nursing } \\
\text { diagnosis fluid } \\
\text { volume excess }^{(14)}\end{array}$ & $\begin{array}{l}\text { Guimarães } \\
\text { HCQCP, } \\
\text { Barros } \\
\text { ALBLB, } \\
\text { Gutierrez } \\
\text { MGR }\end{array}$ & $\begin{array}{l}2000 / \\
\text { Brazil }\end{array}$ & $\begin{array}{l}\text { Clinical } \\
\text { validation, } \\
\text { Fehring's } \\
\text { model }\end{array}$ & $\begin{array}{l}\text { Clinical } \\
\text { assessment } \\
\text { by two expert } \\
\text { nurses }\end{array}$ & $\begin{array}{l}\text { Major DCs: Adventitious breath sounds and blood } \\
\text { pressure changes; } \\
\text { Minor DCs: Edema, orthopnea, intake exceeds output, } \\
\text { changes in respiratory pattern, increased central venous } \\
\text { pressure and altered electrolytes }\end{array}$ \\
\hline $\begin{array}{l}\text { Nursing diagnoses } \\
\text { Decreased Cardiac } \\
\text { Output and Excess } \\
\text { Fluid Volume: } \\
\text { Clinical validation } \\
\text { in patients with } \\
\text { decompensated } \\
\text { heart failure }\end{array}$ & Barth QCM & $\begin{array}{l}2008 / \\
\text { Brazil }\end{array}$ & $\begin{array}{l}\text { Clinical } \\
\text { validation, } \\
\text { Fehring's } \\
\text { model }\end{array}$ & $\begin{array}{l}\text { Clinical } \\
\text { assessment by } \\
\text { two nurses }\end{array}$ & $\begin{array}{l}\text { For Decreased Cardiac Output, major DCs: } \\
\text { Fatigue, dyspnea, edema, orthopnea, paroxysmal nocturnal } \\
\text { dyspnea, increased central venous pressure. Minor } \\
\text { DCs: hepatomegaly, weight gain, jugular vein distension, } \\
\text { palpitations, crackles, oliguria, cough, clammy skin, skin } \\
\text { color changes. DCs which require cardiac output } \\
\text { measures through Swan Ganz catheter were not } \\
\text { assessed. } \\
\text { For Excess Fluid Volume, major DCs: Dyspnea, } \\
\text { orthopnea, edema, positive hepatojugular reflex, paroxysmal } \\
\text { nocturnal dispnea, pulmonary congestion, increased central } \\
\text { venous pressure. Minor DCs: Weight gain, hepatomegaly, } \\
\text { jugular vein distension, crackles, oliguria, decreased } \\
\text { hemoglobin, decreased hematocrit. }\end{array}$ \\
\hline $\begin{array}{l}\text { Nursing Diagnoses } \\
\text { in heart transplanted } \\
\text { patients in } \\
\text { the mediate } \\
\text { postoperative period } \\
\text { and Validation } \\
\text { of the diagnosis } \\
\text { considered the } \\
\text { most characteristic: } \\
\text { Spiritual Distress }{ }^{(16)} \\
\end{array}$ & Matos SS & $\begin{array}{l}2009 / \\
\text { Brazil }\end{array}$ & $\begin{array}{l}\text { Content } \\
\text { validation, } \\
\text { Fehring's } \\
\text { model }\end{array}$ & Not applicable & $\begin{array}{l}\text { Major DCs: expresses sudden changes in spiritual } \\
\text { practices, lack, of hope, verbalizes being separated from } \\
\text { support system, disinterest in reading spiritual literature; } \\
\text { Minor DCs: disinterest in reading spiritual reading, poor } \\
\text { coping, anger, expresses hopelessness, inability to experience } \\
\text { the transcendent, requests to see a religious leader, expresses } \\
\text { lack of courage, refuses interactions with significant others, } \\
\text { guilt, expresses lack of meaning in life, inability to be } \\
\text { introspective }\end{array}$ \\
\hline $\begin{array}{l}\text { Clinical validation } \\
\text { of the nursing } \\
\text { diagnosis } \\
\text { Innefective } \\
\text { Airway Clearance } \\
\text { in children and } \\
\text { adolescents } \\
\text { submitted to } \\
\text { surgical correction } \\
\text { of congenital heart }_{\text {diseases }}^{(17)}\end{array}$ & Pileggi SO & $\begin{array}{l}2007 / \\
\text { Brazil }\end{array}$ & $\begin{array}{l}\text { Content } \\
\text { and clinical } \\
\text { validation, } \\
\text { Hoskins' } \\
\text { model }\end{array}$ & $\begin{array}{l}\text { Not applicable } \\
\text { to the content } \\
\text { validation. To } \\
\text { the clinical } \\
\text { validation, } \\
\text { clinical } \\
\text { assessment by } 2 \\
\text { expert nurses }\end{array}$ & $\begin{array}{l}\text { Major DCs: Adventitious breath sounds, ineffective cough, } \\
\text { changes in respiratory rate and changes in respiratory rbythm; } \\
\text { Minor DCs: Dyspnea, diminished breath sounds, } \\
\text { restlessness, orthopnea, cyanosis, absent congh, excessive } \\
\text { sputum. } \\
\text { Irrelevant DCs: Difficulty vocalizing, wide-eyed. } \\
\text { In the clinical validation, there was } 97.7 \% \text { agreement about } \\
\text { the presence of the ND among the experts; only one DC } \\
\text { obtained confiability coefficient (0.67): "absent cough". The } \\
\text { total score of the ND was } 0.70 \text {. }\end{array}$ \\
\hline $\begin{array}{l}\text { Behavior of } \\
\text { the definining } \\
\text { characteristics } \\
\text { of the nursing } \\
\text { diagnoses Fear and } \\
\text { Anxiety identified } \\
\text { in the immediate } \\
\text { preoperative } \\
\text { period of patients } \\
\text { submitted to elective } \\
\text { surgeries }^{(18)}\end{array}$ & $\begin{array}{l}\text { Suriano } \\
\text { MLF }\end{array}$ & $\begin{array}{l}\text { 2005/ } \\
\text { Brazil }\end{array}$ & $\begin{array}{l}\text { Clinical } \\
\text { validation, } \\
\text { Fehring's } \\
\text { model }\end{array}$ & $\begin{array}{l}\text { Clinical } \\
\text { assessment } \\
\text { by } 5 \text { expert } \\
\text { nurses and one } \\
\text { psychologist }\end{array}$ & $\begin{array}{l}\text { For Fear, major DCs: fear of death, dry mouth, } \\
\text { increased respiraory rate, excitement, verbalization, } \\
\text { nervousism, increased tension and aprehension. } \\
\text { For Anxiety, major DCs: aprehension, nervousism, } \\
\text { tension, alertness, anxiety, anguish, verbalizing, dry mouth, } \\
\text { increased perspiration, shaky voice, insomnia and urinary } \\
\text { urgency. }\end{array}$ \\
\hline
\end{tabular}

Among the seven original articles, four were published in national journals and three were published in an international journal. A portion of the results of the Barth's ${ }^{(15)}$ master's thesis was published in an international journal in 2010. Because the thesis describes the validation of two NDs and the article described only the validation of one ND, we only considered the thesis for this review.

Four out of the 11 reports included were conducted at USP-SP, two at USP-RP, two at UNIFESP-SP, one at UFRGS-RS, one at UFMG-MG, and one at UFCSPA-RS. Ten reports validated the DCs of NDs, and one report validated the diagnostic label, definition and DCs.
Five reports used Fehring's ${ }^{(5)}$ modified expert selection criteria, three used criteria created by the authors themselves, and three did not clearly state the selection criteria.

\section{DISCUSSION}

Research on nursing classifications and their use grant professional actions visibility and scientificity ${ }^{(19)}$. Asking if a ND is clinically valid is asking if the ND was properly identified, excluding other diagnoses that might share some common characteristics ${ }^{(20)}$. 
Brazil has 117 Higher Education Institutions (HEI) with face-to-face courses, out of which $41 \%$ are public, and $59 \%$ are private. In the Southeastern region, there are $43.6 \% ; 23.1 \%$ are in the Northeast; $18.8 \%$ are in the South; $10.3 \%$ are in the Midwest; and $4.3 \%$ are in the Northern regions ${ }^{(21)}$. In this review, RGs on the nursing process prevailed in the Southeast, which reflected the higher scientific production on the validation of NDs in the field of cardiology in this region.

Brazil has 41 stricto Sensu Nursing Graduate Programs accredited by CAPES, out of which 39 are public universities and two areprivate ones. Although only $26.4 \%$ of the enrollments in HEIs with face-to-face courses occur in public institutions, most professors with a doctoral degree are found in these institutions $(65.1 \%)$. Thus, in this review, the scientific production on the validation of NDs in cardiology (and other fields) of the graduate programs in public universities stood out, mainly in the Southeastern and Southern regions.

The scarcity of studies on the validation of NDs in Brazil has been verified previously ${ }^{(22)}$. This review verified low scientific production on the validation of NDs in the field of cardiology within the last decade, which can make it difficult to develop future research about nursing interventions ${ }^{(23)}$. The publication in national journals with English versions, or international journals, provides the national experience with more visibility.

Seven out of the eight studies which used the clinical validation model validated diagnoses in the psychobiological area ${ }^{(8,11-15,17)}$. Only one study had clinical validation of NDs in the psychosocial area ${ }^{(18)}$. Those that used the content validation model validated NDs in the psychosocial $^{(11)}$, psychospiritual ${ }^{(16)}$ and psychobiologi$\mathrm{cal}^{(9)}$ areas. The prevalence of NDs in the psychobiological area over other areas has been evidenced before in patients with heart diseases ${ }^{(10,24-26)}$. The findings of this review can suggest that, although human responses in the psychosocial and psychospiritual areas are less frequently evidenced in the studies, their importance in the field of cardiology has become more clear. The content validation of NDs in these areas is an important step that allows their future clinical validation.

Approximately $91 \%$ of the studies validated the DCs of the NDs. Taking into account the few studies that

\section{REFERENCES}

1. Amante LN, Rossetto AP, Schneider DG. Nursing care systematization at the Intensive Care Unit (ICU) based on Wanda Horta's theory. Rev Esc Enferm USP. 2009; 43(1):54-64.

2. Garcia TR, Nóbrega MM. [Nursing process: from theory to the practice of care and research]. Esc Anna Nery Rev Enferm [Internet]. 2009 [cited 2012 Set 10];13(1):188-93. validated other components of the NDs in Brazil, it is important that the label, definition, risk factors, related factors and the taxonomy itself are validated ${ }^{(22)}$.

The revised studies mostly used Fehring`s validation model with changes of his expert selection criteria. Fehring`s proposed criteria seem to be the most indicated and predominant when it comes to studies of diagnostic validation ${ }^{(10,27)}$. The partial adoption of Fehring`s criteria in the country is related to the difficulty in fully complying with them, because of its demand for experts to hold a master's degree in nursing, and research with published studies on NDs. The time of clinical experience has been used as an indicator of expertise, and the sample size relates to the availability of professionals with the established competence and the desired power of statistical representation (20). The use of other professional categories as experts ${ }^{(9,13)}$ raises reflections about the suitability of these professionals' judgment, since it is about nursing phenomena.

\section{CONCLUSION}

The NDs validated in the field of cardiology in Brazil from 2000 to 2010 were activity intolerance (00092); decreased cardiac output (00029); spiritual distress (00066); deficient knowledge (00126); excessive fluid volume (00026); ineffective airway clearance (00031); ineffective peripheral tissue perfusion (00204); fear (00148); anxiety (00146); (acute) pain (00132). The scientific production on the validation of NDs in the cardiology field of the graduate programs in public universities stood out, mainly in the Southeastern and Southern regions. The clinical validation model was used to validate NDs in the psychobiological area, whereas the content validation model was mainly used to validate NDs in the psychosocial and psychospiritual areas. The most commonly validated components of the NDs were the DCs. Fehring's validation models and his modified expert selection criteria prevailed. The knowledge produced in this review can support future studies about the pertinence of the content of the nursing outcomes for the assessment of the efficacy of the nursing interventions in the country. There must be other studies that validate components other than the DCs, with expert selection criteria clearly stated.
Portuguese Available from: http:/ /www.scielo.br/pdf/ean/ v13n1/v13n1a26.pdf

3. Lira AL, Albuquerque JG, Lopes MV. [Nursing diagnoses profile presented by renal transplanted patients]. Rev Enferm UERJ. 2007; 15(1):13-9. Portuguese.

4. NANDA International. Nursing diagnoses 2009-2011: definitions and classification. Oxford: Wiley-Blackwell; 2008.

5. Fehring RJ. Methods to validate nursing diagnoses. Heart 
Lung. 1987; 16:(6 Pt 1):625-9.

6. Gordon M, Sweeney MA. Methodological problems and issues in identifying and standardizing nursing diagnoses. ANS Adv Nurs Sci.1979; 2(1):1-15.

7. Hoskins LM. Clinical validation methodologies for nursing diagnosis research. In: Carroll-Johnson RM, editor. Classification of nursing diagnosis: proceedings of the eighth conference. Philadelphia: Lippincott; 1989. p. 126-31.

8. Rodrigues CG, Moraes MA, Sauer JM, Kalil RA, Souza EN. Nursing diagnosis of activity intolerance: clinical validation in patients with refractory angina. Int J Nurs Terminol Classif. 2011; 22(3):117-22.

9. Lopes JL, Altino D, Silva RC. Content validation of current and new defining characteristics of the nursing diagnosis: decreased cardiac output. Acta Paul Enferm. 2010;23(6):764-8.

10. Galdeano LE, Rossi LA, Pelegrino FM. Content validation of the "deficient knowledge" nursing diagnosis. Acta Paul Enferm. 2008; 21(4):549-55.

11. Silva RC, Cruz DA, Bortolotto LA, Irigoyen MC, Krieger EM, Palomo JS, et al. Ineffective peripheral tissue perfusion: clinical validation in patients with hypertensive cardiomiopathy. Int J Nurs Terminol Classif. 2006; 17(2):97-107.

12. Oliva AP, Cruz DA. [Decreased cardiac output diagnosis: clinical validation in post-operative heart surgery patients]. Ciênc Cuid Saúde. 2002;1(1):201-5. Portuguese.

13. Corrêa CG, Cruz DA. Pain: clinical validation with postoperative heart surgery patients. Nurs Diagn. 2000;11(1)5-14.

14. Guimaräes HC, Barros AL, Gutierrez MG. [Identification of defining characteristics of the nursing diagnosis fluid volume excess]. Rev Latinoam Enferm. 2000;8(2):68-73. Portuguese.

15. Barth QC. Diagnósticos de enfermagem de débito cardíaco diminuído e volume excessivo de líquidos: validação clínica em pacientes com insuficiência cardíaca descompensada [dissertação]. Porto Alegre: Universidade Federal do Rio Grande do Sul, Escola de Enfermagem; 2008.

16. Matos SS. Diagnósticos de enfermagem em pacientes no pós-operatório mediato de transplante cardíaco e validação do diagnóstico considerado mais característico: angústia espiritual [tese]. Belo Horizonte: Universidade Federal de Minas Gerais, Escola de Enfermagem; 2009.

17. Pileggi SO. Validação clínica do diagnóstico de enfermagem. Desobstrução ineficaz de vias aéreas de crianças e adolescentes submetidos à correção cirúrgica de cardiopatia congênita [dissertação]. Ribeirão Preto: Universidade de São Paulo de
Ribeirão Preto, Escola de Enfermagem; 2007.

18. Suriano ML. Comportamento das características definidoras dos diagnósticos de enfermagem Medo e Ansiedade identificados no pré-operatório imediato de pacientes submetidos a cirurgias eletivas [tese]. São Paulo: Universidade Federal de São Paulo, Escola Paulista de Medicina; 2005.

19. Barros AL. Classification of Nursing Diagnoses and Interventions: NANDA and NIC. Acta Paul Enferm. 2009; 22 (Espec - 70 Anos):864-7.

20. Carvalho EC, Mello AS, Napoleão AA, Bachion MM, Dalri MC, Canini SR. [Nursing diagnosis validation: reflection on difficulties faced by researchers]. Rev Eletr Enf [Internet]. 2008 [cited 2012 Set 10];10(1):235-40. Portuguese. Available from: http://www.fen.ufg.br/fen_revista/v10/ n1/v10n1a22.htm

21. Brasil. Ministério da Educação. Instituto Nacional de Estudos e Pesquisas Educacionais Anísio Teixeira o Técnico. Censo da Educação Superior de 2009 [Internet]. Brasilia: Ministério da Educação; 2010. [citado 2011 Fev 15]. Disponível em http://www.anaceu.org.br/conteudo/noticias/resumo_ tecnico2009.pdf

22. Chaves EC, Carvalho EC, Rossi LA. VValidation of nursing diagnoses: validated types, patterns and components validated]. Rev Eletrônica Enferm [Internet]. 2008 [cited 2012 Set 10];10(2):513-20. Portuguese. Available from: http:// www.fen.ufg.br/fen_revista/v10/n2/v10n2a22.htm

23. Creason NS. Clinical validation of nursing diagnoses. Int J Nurs Terminol Classif. 2004;15(4): 123-32.

24. Cordeiro RL. Reabilitação progressiva: necessidade atual da assistência de enfermagem ao paciente cardíaco [dissertação]. Rio de Janeiro: Universidade Federal do Rio de Janeiro, Escola de Enfermagem Ana Nery; 1980.

25. Guerriero AL, Guimarães HC, Maria VL. [Nursing diagnoses of the adult patient in the first cardiac postsurgery]. Acta Paul Enferm. 2000;13(2):59-67. Portuguese.

26. Lima LR, Stival MM, Lima LR. Nursing iagnoses in patients post-angioplasty transluminal percutaneous coronary based on the horta's assumption. Rev Enferm UFPE. 2008;2(3):205-12.

27. Carvalho EC, Aguiar AS, Joventino ES, Fontenele FC, Moreira RP, Melo RP. Critérios para seleção de experts em estudos de validação de diagnósticos [resumo]. In: $10^{\circ}$ Simpósio Nacional de Diagnóstico em Enfermagem; 2010 Ago 4-7; Brasília. Livro de resumos. Brasília: ABEn; 2010. p.787-9. 